\title{
Daya Saing Komoditas Ubi Kayu dengan Internalisasi Biaya Transaksi di Kabupaten Lampung Tengah, Lampung, Indonesia
}

\section{(Competitiveness of Cassava Commodity with Internalization of Transaction Cost in Central Lampung, Lampung, Indonesia)}

\author{
Zulkarnain $^{1 \%}$, Wan Abbas Zakaria ${ }^{2}$, Dwi Haryono ${ }^{2}$, Ktut Murniati ${ }^{2}$ \\ ${ }^{1}$ Program Studi Agribisnis Sekolah Tinggi Ilmu Pertanian Dharma Wacana Metro \\ ${ }^{2}$ Program Pascasarjana Agribisnis Fakultas Pertanian Universitas Lampung \\ `Email korespondensi: zulfadhilalzabir@gmail.com
}

\begin{abstract}
Cassava is a multifunctional plant that acts as a raw material for alternative energy sources, food and feed. Cassava production must be increased so that it is highly competitive. The research objective was to analyze the cassava farming transaction costs; analyze superior commodities; analyze the competitiveness of cassava; and analyze the impact of policy alternatives on the commodity system in Central Lampung. The research was conducted in Central Lampung using a survey method to 131 cassava farmers who were taken purposively. The analysis used is Transaction Cost (TrC); Location Quotient; PAM (Policy Analysis Matrix); and Sensitivity. The results of the study (1) the transaction cost of cassava was Rp. 356,507.40/ha Ifarmer/season, (2) cassava farming has an $L Q$ value of 1.06 which means that the cassava plant is a competitive superior crop, (3) cassava farming has competitiveness in cassava production so that it is feasible to continue to be developed. (4) the sensitivity analysis of cassava is sensitive to changes in the decline in output prices and sensitive to changes in the increase in input prices with a maximum percentage value.The suggestion is that the government should make an output price policy for cassava farmers in the form of a Regional Minimum Price (HMR) so that the competitiveness of cassava is increased and sustainable.
\end{abstract}

Keywords: competitiveness; internalization; potential; transaction; cassava

\begin{abstract}
Abstrak. Ubi kayu merupakan tanaman multifungsi yang berperan sebagai bahan baku sumber energi alternatif, pangan serta pakan. Produksi ubi kayu harus ditingkatkan supaya berdaya saing tinggi. Tujuan penelitian yaitu menganalisis biaya transaksi usahatani ubi kayu; menganalisis komoditas unggulan; menganalisis daya saing ubi kayu; dan menganalisis dampak alternatif kebijakan dalam sistem komoditas di Kabupaten Lampung Tengah. Penelitian dilaksanakan di Kabupaten Lampung Tengah dengan menggunakan metode survei kepada 131 petani ubikayu yang diambil secara purposive. Analisis yang digunakan yaitu Transaction Cost $(\operatorname{TrC})$; Location Quotient; PAM (Policy Analysis Matrix); dan Sensitivitas. Hasil penelitian (1) biaya transaksi ubi kayu sebesar Rp. 356.507,40/ha/petani/musim, (2) usahatani ubi kayu memiliki nilai LQ sebesar 1,06 artinya tanaman ubi kayu termasuk tanaman unggulan yang berdaya saing, (3) usahatani ubi kayu memiliki daya saing dalam produksi ubi kayu sehingga usahatani ubi kayu layak untuk terus dikembangkan, (4) analisis sensitivitas ubi kayu peka terhadap perubahan penurunan harga output dan peka terhadap perubahan kenaikan harga input dengan nilai persentase maksimal. Sarannya adalah pemerintah harus membuat kebijakan harga output untuk petani ubi kayu yang berupa Harga Minimum Regional (HMR) supaya daya saing ubi kayu lebih meningkat dan berkelanjutan.
\end{abstract}

Kata kunci: daya saing; internalisasi; potensi; transaksi; ubi kayu

\section{PENDAHULUAN}

Sektor pertanian memberikan kontribusi dalam pengembangan pembangunan di Provinsi Lampung. Sejak tahun 2016 - 2019, sumbangan sektor pertanian terhadap PDRB Provinsi Lampung terus meningkat (Badan Pusat Statistik, 2019). Besarnya kontribusi sektor pertanian tersebut tidak terlepas dari dukungan subsektor tanaman pangan (Zulkarnain et al., 2010; Leksono et al., 2018). Tanaman pangan yang ditingkatkan produksinya untuk mendukung kebutuhan pangan nasional adalah ubi kayu. Perdagangan ubi kayu mengalami perkembangan, hal ini dikarenakan meningkatnya permintaan ubi kayu oleh konsumen (Pramesti et al., 2017). Ubi kayu merupakan komoditas tanaman pangan yang memiliki potensi untuk meningkatkan pertumbuhan ekonomi (Yuliati et al., 2019).

Ubi kayu memiliki kandungan karbohidrat yang dapat menggantikan sumber pangan sehingga memperkokoh ketahanan pangan (Machfudz \& Khoiriyah, 
2013). Permintaan ubi kayu mengalami peningkatan setiap tahunnya baik kebutuhan pangan dan industri (Rozi \& Pudjiastuti, 2019), hal ini dikarenakan terdapatnya program pemerintah menggunakan energi alternatif dari hasil pertanian (liquid biofuel) seperti biodiesel dan bioetanol (Dahdah et al., 2020) serta diversifikasi pangan berbasis pangan lokal ubi kayu dengan memanfaatkan umbi dan daunnya (Sinaga et al., 2019; Atikah, 2020) mengacu pada Peraturan Menteri Pertanian Nomor : 15/Permentan/RC.110/2010.

Ubi kayu diolah menjadi tepung tapioka yang digunakan sebagai bahan baku atau bahan tambahan industri hilir (Zulkarnain et al., 2020). Permintaan ubi kayu terus bertambah sehingga perlu adanya peningkatan produktivitas (Lanamana \& Philipus, 2020). Kebutuhan ubi kayu dalam negeri mengalami kekurangan. Untuk memenuhi kebutuhan ubi kayu, pemerintah melaksanakan impor. Menurut Suharyo Husain, Ketua Masyarakat Singkong Indonesia (MSI) menyampaikan harga tepung tapioka impor Rp. 3.500,00 - Rp. 4.000,00 per kilogram, sebaliknya harga jual ubikayu lokal Rp. 1.000,00/kilogram sehingga tepung tapioka dijual dengan harga minimal Rp. 6.000,00/kilogram. Perbedaan harga tersebut membuat industri hilir lebih memilih tepung tapioka impor daripada tepung tapioka lokal.

Peningkatan daya saing memerlukan berbagai upaya seperti pengembangan subsidi pertanian yang berbentuk subsidi sarana produksi (Sari \& Retnaningsih, 2020). Subsidi tersebut diberikan kepada petani sesuai dengan kebutuhan lahan yang di ikuti kebijakan harga output (Andriati \& Sudana, 2011). Subsidi input bertujuan mengurangi biaya produksi sehingga meningkatkan produksi dan pendapatan petani (Sari \& Fahmi, 2018). Nilai output dibandingkan biaya input menentukan seberapa besar pendapatan yang diterima petani (Zakaria et al., 2020). Kebijakan tersebut untuk membantu petani dalam meningkatkan produktivitas serta keunggulan komparatif dan kompetitif dalam usahatani ubi kayu.

Selain itu, kebijakan pemerintah yang berkaitan dengan pemanfaatan bahan bakar nabati yang tertuang dalam Perpres No.5 tahun 2006 tentang kebijakan energi nasional dan undang-undang No. 30 tahun 2007 tentang energi. Ubi kayu mengandung sumber protein nabati. Ubi kayu sebagai bahan baku sumber energi telah meningkatkan persaingan permintaan ubi kayu yang dipergunakan untuk pangan, pakan dan energi (food, feed, fuel) (Kusmaria et al., 2017). Kebijakan pemerintah terkait energi nasional menargetkan tahun 2025 pemakaian bahan bakar nabati mencapai $5 \%$ dalam bauran energi nasional (Kementerian Perindustrian, 2008).

Daya saing diukur melalui dua pendekatan yaitu keuntungan dan efisiensi. Tingkat keuntungan yang dihasilkan terdiri dari keuntungan privat dan keuntungan sosial. Oleh karena itu, daya saing dapat dilihat dari dua faktor yaitu keunggulan komparatif dan keunggulan kompetitif (Pearson et al, 2005). Daya saing dapat dicapai jika perekonomian tidak terjadi distorsi (Muslika \& Tamami, 2019). Dalam kegiatan usahatani, terdapat biaya transaksi yang dikeluarkan secara langsung selain biaya produksi (Bromley \& Cernea, 1989). Biaya transaksi sulit dihindari sehingga menimbulkan tekanan ekonomi bagi petani karena terjadinya transfer surplus yang cukup besar dari petani ke pihak lain (Zulkarnain \& Mangiring, 2017). Meskipun biaya transaksi sulit dihindari tetapi dapat diminimalisasi supaya keuntungan yang diperoleh maksimal (Anggraini et al., 2013; Zulkarnain \& Mangiring, 2017).

Penggunaan sumber daya menentukan daya saing usahatani dalam menghasilkan komoditi dibandingkan dengan komoditi impor (Yuliati et al., 2019), sehingga potensi dan keunggulan komoditas sebagai basis (Saragih et al., 2021) perlu diketahui untuk mendukung daya saing ubi kayu. Peningkatan produksi yang tanpa diikuti 
oleh kenaikan harga jual produk yang bersangkutan, tidak menjamin tingkat kesejahteraan petani sebagai produsen (Zulkarnain et al., 2010). Penelitian mengenai daya saing ubikayu yang telah dilakukan (Pramesti et al., 2017; Ramadan N, 2018; Rosanti et al., 2018; Yuliati et al., 2019) tidak memasukan biaya transaksi dalam daya saing ubi kayu yang berkaitan dengan proses produksi sehingga secara rasional keuntungan privat dan keuntungan sosial yang diperoleh belum maksimal. Berdasarkan rumusan masalah diatas, maka tujuan penelitian ini adalah menganalisis biaya transaksi usahatani ubikayu di Kabupaten Lampung Tengah; menganalisis komoditas unggulan (basis) di Kabupaten Lampung Tengah; menganalisis daya saing produksi ubikayu di Kabupaten Lampung Tengah; dan menganalisis dampak alternatif kebijakan dalam sistem komoditas di Kabupaten Lampung Tengah.

\section{METODE PENELITIAN}

Lokasi penelitian di Kecamatan Terusan Nunyai dan Kecamatan Rumbia Kabupaten Lampung Tengah. Lokasi penelitian ditentukan secara sengaja (purposive) dengan pertimbangan sebagai salah satu sentral produksi tanaman ubi kayu di Provinsi Lampung (Badan Pusat Statistik Provinsi Lampung, 2019).

Metode yang digunakaan yatu metode diskriptif kuantitatif. Jenis data terdiri data primer dan data sekunder. Data primer adalah data yang didapatkan dari hasil wawancara langsung pada petani tanaman ubi kayu di Kecamatan Terusan Nunyai dan Kecamatan Rumbia Kabupaten Lampung Tengah. Data Sekunder adalah data dari lembaga terkait, laporan, publikasi dan pustaka lainnya. Teknik pengumpulan data antara lain interview (Wawancara), observasi (Pengamatan Langsung), dokumentasi, dan kuisoner.

Populasi penelitian sebanyak 1.424 petani ubikayu yang terdiri dari 473 petani di Desa Bandar Agung dan 951 petani di Desa Ruki Basuki. Teknik Pengambilan sampel tersebut didapatkan berdasarkan perhitungan dengan metode purposive, kemudian dilakukan proporsi untuk sampel (Sugiarto et al., 2003). Jumlah sampel di Desa Bandar Agung sebanyak 66 sampel dan di Desa Ruki Basuki sebanyak 71 sempel.

Analisis Data yaitu (1) analisis Transaction Cost (TrC), (2) analisis Location Quotient (LQ), (3) analisis Policy Analysis Matrix (PAM). , (4) analisis sensitivitas.

Analisis Transaction Cost $(\operatorname{TrC})$. Transaction cost atau biaya transaksi yang dihadapi petani tidak selalu sama. Perbedaan tersebut disebabkan kondisi sosial, property right, dan kondisi pasar yang dihadapi petani (Saidah, 2018). Perhitungan biaya transaksi menurut North \& Thomas (1973), sebagai berikut:

$\operatorname{TrC}=\sum \mathrm{Zij}$

Keterangan :

$\begin{array}{rlll}\mathrm{TrC} & = & \text { Transaction Cost } & \ldots(\mathrm{Rp} .) \\ \mathrm{Zij} & = & \text { Komponen } & \\ & \text { Transaction Cost } & \ldots(\mathrm{Rp} .)\end{array}$

Analisis Location Quotient (LQ). Analisis untuk mengetahui potensi komoditas unggulan di Kabupaten Lampung Tengah yang mungkin dikembangkan untuk mendukung agroindustri tapioka yaitu analisis LQ. Analisis LQ bertujuan menentukan komoditas unggulan dari sisi supply (Kohar \& Suherman, 2006). Secara matematis, formula LQ dapat dituliskan sebagai berikut:

$\mathrm{LQ}=\mathrm{X}_{\mathrm{i}} / \mathrm{X}_{\mathrm{t}} / \mathrm{Y}_{\mathrm{i}} / \mathrm{Y}_{\mathrm{t}}$

Keterangan

$$
\begin{aligned}
\mathrm{Xi}= & \text { Produksi komoditas ubi kayu di } \\
& \text { Kab. Lampung Tengah }(\mathrm{kg}) \\
\mathrm{Xt}= & \text { Produksi seluruh komoditas di } \\
& \text { Kab. Lampung Tengah }(\mathrm{kg}) \\
\mathrm{Yi}= & \text { Produksi komoditas ubi kayu di } \\
& \text { Provinsi Lampung }(\mathrm{kg})
\end{aligned}
$$


$\mathrm{Yt}=$ Produki seluruh komoditas di Provinsi Lampung (kg)

Interpretasi hasil perhitungan LQ sebagai berikut:

1) LQ > 1, berarti tanaman tersebut termasuk ke dalam tanaman unggulan (basis).

2) $\mathrm{LQ}=1$, berarti tanaman tersebut termasuk ke dalam tanaman non basis.

3) $\mathrm{LQ}<1$, berarti tanaman tersebut termasuk ke dalam tanaman tertinggal (non basis).
Analisis Policy Analysis Matrix (PAM). Analisis PAM (Policy Analysis Matrix bertujuan mengetahui keuntungan finansial, keuntungan ekonomi, dan dampak kebijakan pemerintah terhadap output, input, input - output, keunggulan komparatif dan keunggulan kompetitif yang merupakan indikator daya saing. Analisis PAM disajikan pada Tabel 1.

Tabel 1. Analisis PAM (Policy Analysis Matrix)

\begin{tabular}{lccccc}
\hline & \multirow{2}{*}{$\begin{array}{c}\text { Penerimaan } \\
\text { Output (Rp.) }\end{array}$} & & \multicolumn{2}{c}{ Biaya (Rp.) } & \multirow{2}{*}{$\begin{array}{c}\text { Keuntungan } \\
\text { (Rp.) }\end{array}$} \\
\cline { 3 - 5 } & $\mathrm{A}$ & $\mathrm{In}$ & $\mathrm{C}$ & $\mathrm{D}$ \\
Harga Privat & $\mathrm{E}$ & $\mathrm{F}$ & $\mathrm{G}$ & $\mathrm{H}$ \\
Harga Sosial & $\mathrm{I}$ & $\mathrm{J}$ & $\mathrm{K}$ & $\mathrm{L}$ \\
\hline Dampak & & & & \\
Kebijakan & & &
\end{tabular}

Sumber: Monke dan Pearson, 1995

Keterangan :

Keuntungan

Finansial

Keuntungan

Ekonomi

Transfer Output

(OT)

Transfer Input

Tradable (IT)

Transfer Faktor non

Tradable (FT)

Transfer Bersih (NT)

Rasio Biaya Privat

(PCR)

Rasio BSD (DRC)

Koefisien Proteksi

Output Nominal

(NCPO)

Koefisien Proteksi

Input Nominal

(NPCI)

Koefisien Proteksi

Efektif (EPC)
(D) $=\mathrm{A}-(\mathrm{B}+\mathrm{C})$

$(\mathrm{H})=\mathrm{E}-(\mathrm{F}+\mathrm{G})$

(I) $=A-E$

(J) $=\mathrm{B}-\mathrm{F}$

(K) $\quad \mathrm{C}-\mathrm{G}$

(L) $=\mathrm{D}-\mathrm{H}$

$=\mathrm{C} /(\mathrm{A}-\mathrm{B})$

$=\mathrm{G} /(\mathrm{E}-\mathrm{F})$

$=\mathrm{A} / \mathrm{E}$

$=\mathrm{B} / \mathrm{F}$

$=(\mathrm{A}-\mathrm{B}) /(\mathrm{E}-\mathrm{F})$
Koefisien

Keuntungan $(\mathrm{PC}) \quad=\quad \mathrm{D} / \mathrm{H}$

Rasio Subsidi Bagi

Produsen (SRP)

$=\quad \mathrm{L} / \mathrm{E}$

Analisis sensitivitas. Analisis sensitivitas digunakan untuk melihat dampak alternatif kebijakan dalam sistem komoditas dengan indikator nilai elastisitas (Kadariah et al., 1978)

Elastisitas $\mathrm{PCR}=\underline{\triangle \mathrm{PCR} / \mathrm{PCR}}$ $\triangle \mathrm{Xi} / \mathrm{Xi}$

Elastisitas DRC $=\underline{\triangle \mathrm{DRC} / \mathrm{DRC}}$ $\triangle \mathrm{Xi} / \mathrm{Xi}$

Dimana, $\mathrm{Xi}$ adalah parameter yang diuji

HASIL DAN PEMBAHASAN

Analisis TrC pada usahatani ubikayu.

Pada kegiatan ekonomi, biaya transaksi sulit dihindari sehingga menimbulkan tekanan ekonomi bagi petani karena terjadinya transfer surplus yang cukup besar dari petani ke pihak lain. Meskipun biaya 
transaksi sulit dihindari maka perlu di tekan serendah mungkin supaya keuntungan maksimal (Anggraini et al., 2013). Biaya transaksi ditekan dengan tujuan untuk meningkatkan kesejahteraan petani (Zulkarnain \& Mangiring, 2017). Meskipun biaya transaksi sulit dihindari, tetapi perlu ditekan sampai efisien, supaya keuntungan yang diperoleh maksimal. Biaya transaksi terjadi akibat adannya transfer kepemilikan (Saidah, 2018). Biaya transaksi menimbulkan kondisi ketidakpastian yang terjadi pada usahatani (Sultan \& Rachmina, 2017). Biaya transaksi pada usahatani ubi kayu di Kabupaten Lampung Tengah disajikan pada Tabel 2.

Tabel 2. Biaya Transaksi Pada Usahatani Ubi Kayu di Kab. Lampung Tengah

\begin{tabular}{|c|c|c|}
\hline Komponen & $\begin{array}{c}\text { Jumlah } \\
\text { (Rp.) }\end{array}$ & $\begin{array}{c}\text { Persen } \\
(\%)\end{array}$ \\
\hline \multicolumn{3}{|c|}{ Biaya transaksi perencanaan } \\
\hline \multirow{2}{*}{$\begin{array}{l}\text { Biaya } \\
\text { koordinasi } \\
\text { Biaya informasi }\end{array}$} & $85.434,43$ & \\
\hline & $43.228,48$ & \\
\hline $\begin{array}{l}\text { Subtotal biaya } \\
\text { transaksi }\end{array}$ & $128.662,9$ & 36,09 \\
\hline \multicolumn{3}{|c|}{ Biaya transaksi pengadaan Input } \\
\hline \multirow{3}{*}{$\begin{array}{l}\text { Biaya informasi } \\
\text { Biaya } \\
\text { koordinasi } \\
\text { Biaya negosiasi }\end{array}$} & $22.199,97$ & \\
\hline & $84.193,53$ & \\
\hline & $80.932,02$ & \\
\hline $\begin{array}{l}\text { Subtotal biaya } \\
\text { transaksi }\end{array}$ & $187.325,5$ & 52,54 \\
\hline \multicolumn{3}{|c|}{ Biaya transaksi pelaksanaan } \\
\hline $\begin{array}{l}\text { Biaya } \\
\text { Monitoring }\end{array}$ & $30.690,23$ & \\
\hline $\begin{array}{l}\text { Biaya } \\
\text { Transportasi }\end{array}$ & $9.828,74$ & \\
\hline $\begin{array}{l}\text { Subtotal biaya } \\
\text { transaksi }\end{array}$ & $40.51,97$ & 11,37 \\
\hline $\begin{array}{l}\text { Total Biaya } \\
\text { Transaksi }\end{array}$ & $356.507,4$ & 100,00 \\
\hline
\end{tabular}

Sumber: Data primer diolah , 2019

Tabel 2 menunjukkan bahwa jumlah biaya transaksi pada usahatani ubi kayu sebesar Rp. 356.507,40 yang terdiri dari biaya transaksi perencanaan, biaya transaksi pengadaan input, dan biaya transaksi pelaksanaan. Biaya yang banyak mengalami pengeluaran yaitu biaya transaksi pengadaan input sebesar Rp. 187.325,52 (52,54\%) yang terdiri dari informasi, koordinasi, dan negosiasi. Biaya koordinasi memberikan kontribusi yaang besar pada pengadaan input usahatani sebesar Rp. 84.193,53. Biaya koordinasi yang dilakukan petani berupa pertemuan dalam bentuk pengajian/arisan (Arifin, 2006). Menurut (Saidah, 2018) biaya koordinasi pada proses usahatani sebesar Rp. 20.865,14. Pertemuan memerlukan biaya informasi yang dibutuhkan sebelum kegiatan usaha dilaksanakan (Suciati et al., 2014). Menurut (Lestari et al., 2018), mengutarakan biaya untuk mencari informasi sebesar Rp. 38.885 .

Biaya transaksi yang sedikit pengeluaran pada usahatani ubi kayu adalah biaya transaksi pelaksanaan sebesar $\mathrm{Rp}$. $40.518,97 \quad(11,37 \%)$ yang terdiri dari monitoring dan transportasi. Menurut (Gunawan et al., 2019) transportasi merupakan alat untuk melakukan perpindahan dari suatu tempat ketempat yang lain. Transportasi yang dipergunakan petani untuk menghadirkan pertemuan yang sedikit jauh dari tempat tinggal adalah sepeda motor. Mobilitas mengunakan sepeda motor lebih nyaman untuk menjangkau lokasi-lokasi yang sulit dikunjungi. Biaya monitoring pada usahatani berupa memantau kondisi ubi kayu yang di panen, biaya menjaga tanaman dan hasil panen serta biaya petugas lapang yang mendampingi usahatani petani.

Biaya perencanaan usahatani bertujuan mengagendakan usahatani yang dilaksanakan dengan koordinasi dalam pertemuan. Petani anggota kelompok melakukan pertemuan untuk mempermudah dalam mendapatkan input atau faktor produksi. Petani yang bertempat tinggal jauh dari tempat pertemuan, maka petani harus mengunakan sepeda motor. Biaya perencanaan usahatani yang dikeluarkan sebesar Rp. 128.662,91 (36,09\%). Menurut 
(Arifin, 2006) mengutarakan bahwa biaya koordinasi berupa biaya operasional organisasi, pertemuan rutin, dan pendapatan yang hilang sebesar Rp. 135,952,00.

\section{Analisis LQ pada usahatani ubikayu.}

Analisis LQ mengambarkan kondisi wilayah sebagai basis atau sentral produksi yang bertujuan untuk memenuhi kebutuhan konsumen. Tanaman ubi kayu menghasilkan nilai LQ yaitu 1,06 (Kabupaten Lampung Tengah). Nilai LQ artinya tanaman ubi kayu di Kabupaten Lampung Tengah merupakan tanaman unggulan dan basis yang memiliki keunggulan komparatif sehingga dapat memenuhi kebutuhan ubi kayu baik di dalam maupun di luar wilayah tersebut. Hasil analisis LQ disajikan pada Tabel 3.

Tabel 3. Analisis Location Quotient tanaman ubi kayu di Kabupaten Lampung Tengah

\begin{tabular}{ccccc}
\hline \multirow{2}{*}{ Tahun } & \multicolumn{4}{c}{ Produksi Komoditas (Ton) } \\
\cline { 2 - 5 } & $\mathbf{X i}$ & $\mathbf{X t}$ & $\mathbf{Y i}$ & $\mathbf{Y t}$ \\
\hline 2014 & 2.310 .814 & 3.417 .332 & 8.034 .016 & 13.141 .546 \\
2015 & 1.224 .711 & 3.461 .212 & 7.387 .084 & 12.576 .659 \\
2016 & 1.073 .574 & 2.698 .577 & 6.481 .382 & 12.261 .750 \\
2017 & 1.096 .905 & 1.317 .660 & 5.451 .312 & 12.255 .657 \\
2018 & 737.508 & 819.508 & 5.055 .614 & 11.947 .044 \\
\hline Jumlah & $6.443,0$ & $11.714,3$ & $32.409,4$ & $62.182,7$ \\
\hline Rata2 & $1.288,7$ & $2.342,9$ & $6.481,9$ & $12.436,5$ \\
\hline LQ & \multicolumn{5}{|c|}{$\mathbf{1 , 0 6}$} \\
\hline
\end{tabular}

Sumber: Data sekunder diolah, 2019

Tabel 3 menunjukkan bahwa nilai LQ yang cukup tinggi dilihat dari produksi ubi kayu atau penawaran ubi kayu yang tinggi jika dibandingkan dengan tanaman lainnya. Tanaman ubi kayu di wilayah tersebut memiliki keunggulan komparatif yang didukung oleh kondisi wilayah yang strategis dengan terdapat agroindustri pengolahan tapioka yang berbahan baku ubi kayu. Selain itu, kecamatan tersebut melakukan pengiriman ubi kayu ke luar wilayah lainnya yang terdapat pabrik tapioka dengan tujuan untuk memenuhi kebutuhan kapasitas.

\section{Analisis PAM pada usahatani ubikayu.}

Dalam analisis finansial digunakan harga privat (private price) sedangkan analisis ekonomi digunakan harga sosial (social price). Harga privat adalah harga yang benar-benar diterima petani. Sedangkan harga sosial yaitu harga pada pasar persaingan sempurna yang mewakili biaya imbang sosial.

\section{Harga privat (private price) dan harga sosial (social price) output}

Harga privat ubi kayu adalah harga ubi kayu yang diterima petani pada waktu menjual hasil panen yaitu sebesar Rp. $1.056,57 / \mathrm{kg}$. Sedangkan harga sosial merupakan harga yang dihitung dengan melakukan pendugaan terhadap harga ubi kayu. Harga sosial ubi kayu diperoleh dari harga yang berlaku pada pasar intenasional atau Free On Board (FOB) dengan harga FOB tapioka Bangkok Maret 2019 sebesar US\$ 502,10 per ton (Commodity Price Data, 2019) ditambah dengan biaya pengapalan dan asuransi sebesar 52,72 US \$/ton kemudian dikalikan dengan harga sosial nilai tukar rupiah sebesar Rp 15.082 /US \$ (Shadow Exchange Rate). Perhitungan tersebut diperoleh harga CIF dalam mata uang domestik Rp. $8.368,15 / \mathrm{kg}$, kemudian ditambahkan dengan biaya bongkar muat, susut dan lain-lain sebesar $3 \%$ dari CIF sebesar Rp. 251,04 dan biaya transportasi ke provinsi sebesar $\mathrm{Rp} 10 / \mathrm{kg}$. Untuk menyetarakan kualitas ubi kayu hasil panen petani dengan kualitas impor, maka 
dilakukan perhitungan konversi proses (Rosanti et al., 2018). Nilai tersebut dikonversikan ke tapioka sebesar $25 \%$ (SKKNI Bidang Pengolahan Tapioka Kementerian Perindustrian, 2019) sehingga didapatkan harga paritas ekspor di pedagang besar Rp. 1.295,38/kg, untuk mendapatkan harga paritas ekspor di tingkat petani, maka harga paritas ekspor pedagang besar dikurangi biaya distribusi ke tingkat petani sebesar Rp 55/kg, sehingga didapatkan harga sosial output ubi kayu sebesar Rp. $1.239,38 / \mathrm{kg}$.

\section{Harga privat (private price) dan harga sosial (social price) input}

Harga privat bibit ubikayu adalah harga yang dibayarkan petani dalam memperoleh bibit. Bibit yang digunakan petani merupakan bibit lokal (hasil panen) oleh karena itu harga sosial bibit sama dengan harga privatnya. Harga privat dan harga sosial sebesar Rp. 8.430,66 per ikat.

Harga privat pupuk adalah harga yang dibayarkan petani untuk mendapatkan pupuk. Harga sosial pupuk urea, TSP/SP-36, KCL, dan NPK/Phonska didasarkan pada harga CIF. (Zakaria et al., 2010) menyatakan bahwa input dan output yang diperdagangkan secara internasional, harga sosialnya dihitung berdasarkan harga perdagangan internasional sehingga komoditas yang diimpor memakai harga CIF. Harga privat dan harga sosial yang disajikan pada Tabel 4.

Tabel 4. Harga privat dan harga sosial pupuk pada usahatani ubi kayu

\begin{tabular}{lcc}
\hline Jenis Pupuk & $\begin{array}{c}\text { Harga } \\
\text { Privat } \\
\text { (Rp. })\end{array}$ & $\begin{array}{c}\text { Harga } \\
\text { Sosial } \\
\text { (Rp.) }\end{array}$ \\
\hline Pupuk Urea & $2.004,38$ & $3.875,76$ \\
Pupuk TSP/SP- & $2.874,67$ & $4.640,09$ \\
36 & & \\
Pupuk KCL & $5.854,02$ & $4.034,22$ \\
Pupuk & $3.092,05$ & $4.824,96$ \\
NPK/Phonska & & \\
Pupuk Kandang & 489,37 & 489,37 \\
\hline
\end{tabular}

Sumber: Data primer dan sekunder diolah, 2019
Tabel 4. menunjukkan bahwa harga privat ubi kayu diperoleh dari daerah penelitian atau harga yang sebenarnya diterima petani. Harga sosial pupuk didapatkan dari CIF pupuk (Commodity Price Data) dikalikan harga sosial nilai tukar uang menjadi Rp. 15.082,63/US\$ (Shadow Exchange Rate) kemudian ditambah dengan biaya bongkar muat, gudang, penyusutan, dan lain-lain sebesar 3 $\%$ dari CIF dan biaya transportasi Rp. 10/kg. Biaya distribusi ke tingkat petani Rp. 55/kg (Zulkarnain et al., 2010). Harga sosial pupuk urea, NPK/Phonska dan TSP/SP-36 lebih besar dari harga privatnya dikarenakan adanya kebijakan pemerintah yang berupa kebijakan subsidi pupuk kecuali pupuk KCL. Pupuk kandang merupakan pupuk yang dipasarkan di dalam negeri, oleh karena itu harga sosial pupuk kandang sama dengan harga privatnya.

Harga privat pestisida ubi kayu adalah harga yang dibayarkan petani dalam memperoleh pestisida. Harga sosial pestisida menurut (Saptana et al., 2004) yaitu harga aktual dikurangi tarif impor sebesar $10 \%$ dan pajak pertambahan nilai $10 \%$, sejalan dengan penelitian (Sukmaya et al., 2017) harga sosial diperoleh dari harga pestisida sebesar $20 \%$.

Harga privat peralatan sama dengan harga sosial yaitu berdasarkan nilai penyusutan (Zulkarnain et al., 2010; (Andala et al., 2014). Hal tersebut dikarenakan peralatan tersebut tidak diperdagangkan di pasar internasional (Hermayanti et al., 2013).

Harga tenaga kerja pada pasar tenaga kerja di Indonesia terutama tenaga kerja tak terdidik (unskilled), tingkat upah yang diberikan sering kali melebihi biaya imbangan (Zulkarnain et al., 2010). Harga sosial tenaga kerja sama dengan harga privat tenaga yang digunakan di daerah penelitian (Malian et al., 2004; Meliyana et al., 2013).

Harga privat lahan adalah harga yang dibayarkan petani dalam memperoleh sewa lahan. Harga sosial lahan didapatkan dari nilai sewa aktual dari tanah untuk tanaman 
alternatif terbaik (Sukmaya et al., 2017). Penentuan harga sosial tanah berdasarkan harga aktual sewa lahan dikarenakan lahan tidak dapat diperdagangkan secara internasional (Widyatami \& Wiguna, 2019).

Harga privat biaya transaksi sama dengan harga sosial yaitu berdasarkan transaksi untuk memperoleh sarana produksi di wilayah penelitian. Hal tersebut dikarenakan biaya transaksi tidak diperdagangkan di pasar internasional.

Harga privat biaya angkut sama dengan harga sosial yaitu berdasarkan nilai tonase jasa pengiriman. Hal tersebut dikarenakan biaya angkut tidak diperdagangkan di pasar internasional (Hermayanti et al., 2013).

Nilai tukar rupiah. Harga sosial nilai tukar adalah harga uang domestik yang dikaitkan dengan mata uang asing pada pasar nilai tukar. Menurut Squire \& Van Der Tak (1975) dalam (Zulkarnain et al., 2010) harga sosial nilai tukar dari SER (Shadow Exchange Rate). Nilai ekspor indonesia pada tahun 2019 sebesar Rp. 14.447.800.000.000,00 sedangkan nilai impor tahun 2019 sebesar Rp. 13.451.100.000.000,00(www.bps.go.id).

Pajak ekspor indonesia pada tahun 2019 sebesar Rp. 39.800.000.000,00 sedangkan pajak impor tahun 2019 sebesar Rp. 1.603.300.000.000,00 (Nota Keuangan dan APBN). Rata-rata nilai tukar Dollar Amerika terhadap Rupiah pada tahun 2019 sebesar Rp. 10.238 (www.bi.go.id). Berdasarkan hasil perhitungan, diperoleh angka konversi baku (SCF) sebesar 0,944. Harga sosial nilai tukar uang (SER) adalah Rp. 15.082,63/US \$.

Analisis keuntungan finansial dan keuntungan ekonomi berdasarkan data penerimaan dan biaya produksi yang terdiri dua yaitu harga privat dan harga sosial. Nilai penerimaan dan biaya produksi dihitung ke dalam biaya privat dan sosial yang dikelompokan ke komponen tradeable dan non tradeable. Berdasarkan perhitungan, maka dapat disusun Matrik Analisis Kebijakan yang disajikan pada Tabel

\section{5.}

Tabel 5. Matrik Analisis Kebijakan usahatani ubi kayu di Kabupaten Lampung Tengah

\begin{tabular}{|c|c|c|c|c|}
\hline \multirow{2}{*}{ Uraian } & \multirow{2}{*}{$\begin{array}{c}\text { Penerimaan } \\
\text { (Rp.) }\end{array}$} & \multicolumn{2}{|c|}{ Biaya (Rp.) } & \multirow{2}{*}{$\begin{array}{c}\text { Keuntungan } \\
\text { (Rp.) }\end{array}$} \\
\hline & & Tradeable & Non Tradeable & \\
\hline Harga privat & $24.455 .483,39$ & $2.932 .100,05$ & $13.104 .650,73$ & $8.418 .732,61$ \\
\hline Harga sosial & $28.686 .824,72$ & $3.629 .103,59$ & $13.073 .295,61$ & $11.920 .425,52$ \\
\hline Divergensi & $(4.231 .341,33)$ & $(697.718,64)$ & $31.355,12$ & $(3.501 .692,91)$ \\
\hline
\end{tabular}

Sumber: Data primer diolah, 2019

\begin{tabular}{ll}
\hline Indikator & \multicolumn{1}{c}{ Nilai } \\
\hline$\prod$ Finansial & $8.418 .732,61$ \\
$\prod$ Ekonomi & $11.920 .425,52$ \\
OT & $(4.231 .341,33)$ \\
IT & $(761.003,54)$ \\
FT & $31.355,12$ \\
NT & $(3.501 .692,91)$ \\
PCR & 0,6089 \\
DRC & 0,5231 \\
NCPO & 0,8525 \\
NPCL & 0,7939 \\
EPC & 0,8612 \\
PC & 0,7062 \\
SRP & $(0,1221)$ \\
\hline
\end{tabular}

\section{Analisis keuntungan finansial dan keuntungan ekonomi}

Usahatani ubi kayu di Kabupaten Lampung Tengah menguntungkan secara finansial maupun ekonomi. Keuntungan privat dan keuntungan sosial usahatani ubi kayu masing-masing bertanda positif yaitu sebesar Rp. 8.418.732,61 dan Rp. 11.988.140,36. Sedangkan keuntungan divergensi bertanda negatif sebesar ( $\mathrm{Rp}$. $3.569 .407,75)$ yang artinya petani menerima keuntungan lebih rendah dari yang seharusnya. 


\section{Analisis kompetitif (PCR) dan komperatif (DRC)}

Daya saing didapatkan nilai PCR (keunggulan kompetitif) dan DRC (keunggulan komparatif). Menurut (Irawati et al., 2015) daya saing merupakan suatu konsep untuk menilai kemampuan produsen dalam memproduksi tanaman dengan kualitas yang baik dan biaya produksi yang rendah. Nilai PCR pada usahatani ubi kayu kurang dari satu sebesar 0,6089 menunjukkan bahwa usahatani ubi kayu sangat unggul secara kompetitif yang artinya untuk menghasilkan satu satuan produk secara finansial dibutuhkan sumber daya domestik sebesar 60,89\%. Sedangkan nilai DRC pada usahatani ubi kayu kurang dari satu sebesar 0,5216 menunjukkan bahwa usahatani ubi kayu sangat unggul secara komparatif yang artinya untuk menghasilkan devisa sebesar satu satuan dibutuhkan sumber daya domestik sebesar $52,16 \%$. Dilihat dari nilai PCR dan DRC, komoditas ubi kayu memiliki potensi besar untuk melakukan ekspor.

\section{Analisis dampak kebijakan pemerintah}

1. Kebijakan pemerintah terhadap output

Nilai Output Transfer (OT) pada usahatani ubi kayu bertanda negatif sebesar (Rp. 4.231.341,33) dan nilai Nominal Protection coefficient on tradeable output (NPCO) kurang dari satu yaitu sebesar 0,8525. Hal ini menunjukkan bahwa penerimaan yang diterima petani lebih rendah dari yang seharusnya. Hal ini disebabkan oleh bentuk pasar ubi kayu tidak bersaing sempurna yang terdapat beberapa pembeli dengan banyak penjual sehingga petani bertindak sebagai price taker (Zakaria et al., 2020; Sugino \& Mayrowani, 2009). Kondisi ini terjadi dikarenakan sifat ubikayu yang mudah rusak (bulky) dan desakan kebutuhan rumah tangga sehingga petani segera menjual ubikayunya (Anggraini et al., 2013; Zakaria et al., 2019). Harga jual ubikayu rendah dapat diatasi apabila petani membentuk asosiasi agribisnis pertanian dengan pendekatan koordinasi horizontal melalui peran pemerintah dengan penentapan harga minimum regional.

2. Kebijakan pemerintah terhadap input

Nilai Transfer Input (IT) pada usahatani ubikayu bertanda negatif sebesar (Rp. 697.718,64) dan nilai Nominal Protection Coefficient on Tradeable Input (NPCI) kurang dari satu yaitu sebesar 0,8078. Hal ini menunjukkan bahwa petani membayar biaya input tradable lebih murah 80,78\% dari yang seharusnya dengan kata lain ada kebijakan subsidi terhadap input tradeable sebesar 19,22 \%. Hal ini disebabkan adanya subsidi pemerintah terhadap input tradeable yang berbentuk kebijakan subsidi pupuk yang diterapkan pemerintah untuk pupuk urea, phonska, SP-36 dan ZA sehingga memberikan keuntungan bagi petani. Kebijakan pupuk bersubsidi sangat dibutuhkan oleh petani yang memiliki modal kecil (Darwis \& Supriyati, 2014). Kebijakan tersebut, petani dapat melakukan pemupukan usahatani ubi kayu sesuai dengan anjuran pemerintah sehingga meningkatkan produksi yang berdampak pada peningkatan pendapatan.

Nilai Transfer Factor (FT) pada usahatani ubikayu positif yaitu sebesar Rp. $35.785,06$. Oleh karena itu, biaya yang dikeluarkan petani membayar biaya input non-tradable lebih besar yang seharusnya. Penyebabnya adalah kebijakan pemerintah pada tenaga kerja yang berupa Upah Minimum Regional (UMR) masih sangat rendah sejalan dengan penelitian (Rosanti et al., 2018). Selain itu, petani mengeluarkan biaya transaksi diluar biaya produksi untuk memperoleh faktor produksi. Biaya transaksi dapat diminimalisir dalam proses usahatani ubi kayu (Patria et al., 2014).

3. Kebijakan pemerintah terhadap input output

Nilai Koefisien Proteksi Efektif (EPC) pada usahatani ubi kayu kurang dari satu yaitu sebesar 0,8590. Kondisi tersebut menunjukkan bahwa kebijakan pemerintah 
yang berupa kebijakan output dan kebijakan input tidak memberikan keuntungan secara nyata bagi petani untuk berproduksi. Hal ini dikarenakan harga jual ubi kayu yang rendah dan kelangkaan pupuk sehingga harga pupuk menjadi tingginya. Menurut (Rosanti et al., 2018) seharusnya kebijakan yang ada dapat memproteksi petani dan mendorong ekspor.

Nilai Subsidy Ratio to Producer (SRP) pada usahatani ubi kayu negatif sebesar $(0,1244)$. Kondisi tersebut menunjukkkan bahwa adanya distorsi pasar dan kebijakan pemerintah terhadap input maupun output pada usahatani ubikayu menyebabkan penurunan keuntungan sebesar 12,44 \% dari keuntungan yang sesungguhnya diterima petani, sehingga kebijakan tersebut belum memberikan peningkatan keuntungan bagi petani ubi kayu.

Nilai Net Transfer (NT) pada usahatani ubikayu bernilai negatif yaitu sebesar (Rp. 3.569.407,75). Kondisi ini berarti bahwa keuntungan yang diterima petani lebih rendah dari yang seharusnya diterima petani.

Nilai Koefisien Proteksi Efektif (EPC) pada usahatani ubi kayu bernilai positif kurang dari satu yaitu 0,8612 yang artinya petani ubi kayu membayar input tradable dan menjual output tidak sesuai dengan harga yang seharusnya (harga sosial). Oleh karena itu, kebijakan pemerintah terhadap input-output tidak memberikan perlindungan yang efektif dan nilai tambah yang besar bagi petani ubi kayu untuk berproduksi.

Nilai Profitability Coefficient (PC) pada usahatani ubikayu bernilai positif kurang dari satu sebesar 0,7023. Kondisi ini berarti bahwa kebijakan pemerintah baik kebijakan output maupun kebijakan input belum memberikan insentif atau rangsangan untuk peningkatan produksi dan produktivitas ubi kayu.

\section{Analisis sensitivitas pada usahatani ubikayu.}

Sensitivitas daya saing ubi kayu akibat pengaruh perubahan dari beberapa komponen penting dalam usahatani ubi kayu maka perlu dilakukan beberapa simulasi yaitu penurunan harga output, kenaikan harga pupuk, kenaikan harga tenaga kerja, keniakan biaya transaksi, dan keniakan biaya angkut terhadap koefisien PCR dan DRC.

Tabel 6. Analisis sensitivitas PCR usahatani ubi kayu di Kabupaten Lampung Tengah.

\begin{tabular}{|c|c|c|c|c|c|c|c|c|}
\hline \multirow[b]{2}{*}{ Uraian } & \multicolumn{4}{|c|}{ PRC } & \multicolumn{4}{|c|}{ DRC } \\
\hline & $\Delta(\%)$ & $\begin{array}{l}\text { PAM } \\
\text { Awal }\end{array}$ & $\begin{array}{l}\text { PAM } \\
\text { Akhir }\end{array}$ & Elastis & $\Delta(\%)$ & $\begin{array}{l}\text { PAM } \\
\text { Awal }\end{array}$ & $\begin{array}{l}\text { PAM } \\
\text { Akhir }\end{array}$ & Elastis \\
\hline $\begin{array}{l}\text { Penurunan harga } \\
\text { jual }\end{array}$ & $28 \%$ & 0,608 & 0,893 & 1,136 & $45 \%$ & 0,523 & 0,559 & 1,148 \\
\hline $\begin{array}{l}\text { Kenaikan harga } \\
\text { pupuk urea }\end{array}$ & $60 \%$ & 0,608 & 0,616 & 1,153 & $40 \%$ & 0,523 & 0,530 & 1,277 \\
\hline $\begin{array}{l}\text { Kenaikan harga } \\
\text { pupuk TSP/SP-36 }\end{array}$ & $60 \%$ & 0,608 & 0,615 & 1,048 & $50 \%$ & 0,523 & 0,529 & 1,212 \\
\hline $\begin{array}{l}\text { Keniakan harga } \\
\text { pupuk KCL }\end{array}$ & $40 \%$ & 0,608 & 0,616 & 1,087 & $70 \%$ & 0,523 & 0,529 & 1,126 \\
\hline $\begin{array}{l}\text { Keniakan harga } \\
\text { pupuk } \\
\text { NPK/Phonska }\end{array}$ & $50 \%$ & 0,608 & 0,616 & 1,088 & $30 \%$ & 0,523 & 0,530 & 1,254 \\
\hline $\begin{array}{l}\text { Keniakan harga } \\
\text { pupuk kandang }\end{array}$ & $20 \%$ & 0,608 & 0,617 & 1,326 & $20 \%$ & 0,523 & 0,531 & 1,329 \\
\hline $\begin{array}{l}\text { Keniakan harga } \\
\text { tenaga kerja }\end{array}$ & $10 \%$ & 0,608 & 0,623 & 2,293 & $10 \%$ & 0,523 & 0,535 & 2,299 \\
\hline $\begin{array}{l}\text { Keniakan biaya } \\
\text { transaksi }\end{array}$ & $90 \%$ & 0,608 & 0,615 & 1,001 & $90 \%$ & 0,523 & 0,528 & 1,004 \\
\hline $\begin{array}{l}\text { Keniakan biaya } \\
\text { angkut }\end{array}$ & $10 \%$ & 0,608 & 0,616 & 1,217 & $10 \%$ & 0,523 & 0,529 & 1,220 \\
\hline
\end{tabular}

Sumber: Data primer diolah, 2019 
Keterangan

$\begin{array}{lll}\text { Elastisitas } & <1 & \begin{array}{l}\text { (Tidak Peka atau } \\ \text { Inelastis) }\end{array} \\ \text { PCR/DRC } & & \begin{array}{l}\text { (Peka atau elastis) } \\ \text { Elastisitas }\end{array}\end{array}$

PCR/DRC

Analisis sensitivitas terhadap koefisien PCR dan DRC digunakan untuk menganalisis perubahan keunggulan kompetitif terhadap penurunan harga output, kenaikan harga pupuk, keniakan harga tenaga kerja, keniakan biaya transaksi, keniakan biaya angkut pada harga privat. Koefisien PCR dan DRC di simulasi dengan berbagai persentase perubahan penurunan dan kenaikan yang disajikan pada Tabel 6 .

\section{Penurunan harga output ubikayu}

Penurunan harga output didasarkan pada persentase penurunan harga FOB ubi kayu. Penurunan harga ubi kayu pada PRC sebesar $28 \%$ dan DRC sebesar $45 \%$ dari harga awal, dengan asumsi bahwa tidak ada perubahan terhadap komponen input. Penurunan harga output ubi kayu menyebabkan nilai PCR dan DRC menjadi lebih besar dari nilai awalnya. Nilai PCR awal sebesar 0,60886 menjadi 0,89294 sedangkan nilai DRC awal 0,52306 menjadi 0,55875 . Hal ini menunjukkan bahwa daya saing usahatani ubi kayu semakin rendah dengan adanya penurunan harga output ubikayu. Penurunan harga ubi kayu di PCR menjadi Rp. 760,73 dan di DRC menjadi Rp. 681,66. Nilai elastisitas PCR dan DRC lebih dari satu yaitu sebesar 1,1362 dan 1,148 yang artinya daya saing usahatani ubikayu peka terhadap penurunan harga ubi kayu. Menurut (Haryanto et al., 2018) menyatakan bahwa semakin besar nilai elastisitas maka dampak perubahan harga yang terjadi semakin besar.

\section{Kenaikan harga input pupuk}

Kenaikan harga input pupuk di PCR dan DRC berdampak pada daya saing ubikayu. Kenaikan harga input pupuk didasarkan pada persentase perubahan harga dari masing-masing jenis pupuk. Kenaikan harga input pupuk pada usahatani ubi kayu menyebabkan nilai PCR dan DRC menjadi lebih besar dari nilai awalnya yang menyebabkan daya saing ubi kayu di Kabupaten Lampung Tengah semakin rendah. Nilai elastisitas dari PCR dan DRC lebih dari satu untuk pupuk urea, TSP/SP36, KCL, NPK/Phonska dan pupuk kandang sehingga menunjukkan bahwa daya saing ubikayu peka terhadap kenaikan harga pupuk. Dari beberapa nilai kenaikan pupuk tersebut baik di PCR maupun DRC, pupuk KCL memiliki kepekaan yang lebih kecil di PCR sebesar $40 \%$ dan lebih besar di DRC sebesar $70 \%$. Pupuk KCL memiliki fungsi yang bermanfaat untuk perkembangan umbi sehingga dapat meningkatkan produktivitas ubikayu. Kemudian kenaikan pupuk kandang di PCR dan DRC memiliki kepekaan yang sama yaitu sebesar 20\% artinya pupuk kandang pada lahan ubi kayu sangat dibutuhkan untuk meningkatkan kesuburan tanah.

\section{Kenaikan harga input tenaga kerja}

Kenaikan harga tenaga kerja pada usahatani ubi kayu menyebabkan nilai PCR dan DRC menjadi lebih besar dari nilai awalnya. Nilai PCR awal sebesar 0,60886 menjadi 0,62315 sedangkan nilai DRC awal 0,52306 menjadi 0,53537. Hal ini menunjukkan bahwa daya saing usahatani ubikayu semakin rendah dengan adanya kenaikan tenaga kerja. Nilai elastisitas $P C R$ dan DRC lebih dari satu yaitu sebesar 2,2930 dan 2,2990. Hal ini menunjukkan bahwa daya saing usahatani ubi kayu peka terhadap kenaikan tenaga kerja apabila biaya transaksi naik menjadi $10 \%$ baik di PCR dan DRC.

\section{Kenaikan biaya transaksi}

Kenaikan biaya transaksi pada usahatani ubi kayu menyebabkan nilai PCR dan DRC menjadi lebih besar dari nilai awalnya. Nilai PCR awal sebesar 0,60886 menjadi 0,61501 sedangkan nilai DRC awal 
0,52306 menjadi 0,52837. Hal ini menunjukkan bahwa daya saing usahatani ubikayu semakin rendah dengan adanya kenaikan biaya transaksi. Nilai elastisitas PCR dan DRC lebih dari satu yaitu sebesar 1,0013 dan 1,0041. Hal ini menunjukkan bahwa daya saing usahatani ubikayu peka terhadap kenaikan biaya transaksi apabila biaya transaksi naik menjadi $90 \%$ baik di PCR dan DRC. Biaya transaksi berdampak pada penurunan pendapatan petani ubikayu. Oleh karena itu, biaya transaksi dapat di tekan seminimal mungkin walaupun dapat berdampak jika biaya transaksi naik menjadi $90 \%$.

\section{Kenaikan biaya angkut}

Kenaikan biaya angkut di PCR dan DRC masing-masing sebesar $10 \%$ dari biaya awal, dengan asumsi bahwa tidak ada perubahan terhadap komponen lain. Kenaikan biaya angkut pada usahatani ubikayu menyebabkan nilai PCR dan DRC menjadi lebih besar dari nilai awalnya. Nilai PCR awal sebesar 0,60886 menjadi 0,61636 sedangkan nilai DRC awal 0,52306 menjadi 0,52952. Hal ini menunjukkan bahwa daya saing usahatani ubi kayu semakin rendah dengan adanya kenaikan biaya angkut. Nilai elastisitas $P C R$ dan DRC lebih dari satu yaitu sebesar 1,2169 dan 1,220. Hal ini menunjukkan bahwa daya saing usahatani ubi kayu peka terhadap kenaikan biaya angkut, hal ini sejalan dengan penelitian (Rosanti et al., 2018). Biaya angkut sangat sensitif mengalami perubahan setelah naik $10 \%$. Kenaikan harga biaya angkut dapat berpengaruh terhadap pendapatan petani ubi kayu dikarenakan jarak tempuh dengan kondisi jalan yang kurang baik dan keterbatasan kendaraan angkut di wilayah tersebut.

\section{SIMPULAN}

Kesimpulan dalam penelitian ini adalah (1) biaya transaksi ubi kayu sebesar Rp. 356.507,40/petani/musim. (2) usahatani ubi kayu di Kabupaten Lampung Tengah memiliki nilai $L Q>1$ yang artinya tanaman ubi kayu merupakan tanaman unggulan (basis) sehingga berdaya saing. (3) usahatani ubi kayu di Kabupaten Lampung Tengah memiliki daya saing dalam produksi ubi kayu sehingga usahatani ubi kayu layak untuk terus dikembangkan, hal ini dapat dilihat dari nilai PCR (Private Cost Ratio) sebesar 0,6089 dan DRC (Domestic Resource Cost) sebesar 0,5231. (4) analisis sensitivitas terhadap daya saing dalam produksi ubi kayu menunjukkan bahwa adanya kepekaan terhadap perubahan penurunan harga output dan ada kepekaan terhadap perubahan kenaikan harga input dengan nilai presentase maksimal, hal ini dapat dilihat dari nilai elastisitas PCR dan DRC untuk harga output dan harga input yang bernilai lebih dari satu.

Saran dalam penelitian ini adalah pemerintah harus membuat kebijakan harga output untuk petani ubi kayu yang berupa Harga Minimum Regional (HMR) supaya daya saing ubi kayu tambah meningkat dan berkelanjutan.

\section{DAFTAR PUSTAKA}

Andala, A., Abidin, Z., \& Situmorang, S. (2014). Keunggulan Kompetitif Dan Komparatif Usahatani Manggis Di Kabupaten Tanggamus. Jurnal IlmuIlmu Agribisnis, 2(3), 214-222. https://doi.org/http://dx.doi.org/10.2396 0/jiia.v2i3.214-222

Andriati, A., \& Sudana, W. (2011). Efektivitas Kebijakan Harga Input dan Output Usahatani Tanaman Pangan pada Berbagai Agroekosistem di Indonesia. Jurnal Penelitian Pertanian Tanaman Pangan, 30(2), 137-144. https://doi.org/10.21082/jpptp.v30n2.20 11.p\%p

Anggraini, N., Hasyim, A. I., \& Situmorang, S. (2013). Analisis Efisiensi Pemasaran Ubi Kayu di Propinsi Lampung. Jurnal Ilmu-Ilmu Agribisnis, 1(1), 80-86. https://doi.org/http://dx.doi.org/10.2396 0/jiia.v1i1.\%25p

Arifin, B. (2006). Transaction Cost Analysis of Upstream-Downstream Relations in 
Watershed Services: Lessons from Community-Based Forestry Management in Sumatra, Indonesia. International Association of Agricultural Economist Conference, 17, $1-17$.

https://doi.org/10.22004/ag.econ.25788

Atikah, T. A. (2020). Pemberdayaan Masyarakat Melalui Pengolahan Singkong menjadi Bahan Baku Produk Olahan Makanan di Desa Tarung Manuah, Kecamatan Basarang, Kabupaten Kapuas. PengabdianMu: Jurnal Ilmiah Pengabdian Kepada Masyarakat, 5(4), 404-409. https://doi.org/https://doi.org/10.33084/ pengabdianmu.v5i4.1346

Badan Pusat Statistik Propinsi Lampung. 2019. Lampung dalam Angka.Badan Pusat Statistik Propinsi Lampung

Dahdah, S. S., Rahim, A. R., Yusuf, M. B., Al Ayubi, M. S., Priambodo, S., \& Hanani, F. (2020). Pemanfaatan Sekam Padi Menjadi Briket Sebagai Energi Alternatif Studi Kasus Desa Wotansari - Balong Panggang. DedikasiMU(Journal of Community Service), 2(1), 182-190. https://doi.org/http://dx.doi.org/10.3058 7/dedikasimu.v2i1.1202

Darwis, V., \& Supriyati, S. (2014). Subsidi Pupuk: Kebijakan, Pelaksanaan, dan Optimalisasi Pemanfaatannya. Analisis Kebijakan Pertanian, 11(1), 45-60. https://doi.org/10.21082/akp.v11n1.201 3.45-60

Gunawan, A. R., Rachmawati, I., \& Meigawati, D. (2019). Peran Dinas Perhubungan Dalam Tata Kelola Angkutan Umum Perkotaan di Kota Sukabumi. DECISION: Jurnal Administrasi Publik, 1(2), 102-108.

Haryanto, L. I., Masyhuri, M., \& Irham, I. (2018). Daya Saing Dan Sensitivitas Usahatani Jagung Di Kabupaten Pacitan. Jurnal Kawistara, 8(3), 213309.

https://doi.org/https://doi.org/10.22146/ kawistara.38363
Hermayanti, N. W., Abidin, Z., \& Santoso, H. (2013). Analisis daya saing usahatani kelapa sawit di kecamatan waway karya kabupaten lampung timur. Jurnal Ilmu Ilmu Agribisnis, 1(1), 4452.

https://doi.org/http://dx.doi.org/10.2396 0/jiia.v1i1.\%25p

Irawati, D. J., Sihombing, L., \& Ginting, R. (2015). Analisis Daya Saing dan Dampak Kebijakan Pemerintah Terhadap Komoditi Padi Sawah di Kecamatan Perbaungan Kabupaten Serdang Bedagai. Journal of Agriculture and Agribusiness Socioeconomics, 4(7), 1-15.

Kadariah, Karlina, L., Gray, C., 1978. Pengantar Evaluasi Proyek. Jakarta: Universitas Indonesia. Fakultas Ekonomi

Kementerian Perindustrian. 2008. https://kemenperin.go.id/artikel/1903/In donesia-Produsen-Utama-Biodiesel

Kohar, A., \& Suherman, A. (2006). Location Quotient (LQ) Analysis for Primer Fish Determination Fisheries Capture at Cilacap Regency. Seminar Nasional Tangkap, Agustus 2006, IPB, 1, 1-10. http://eprints.undip.ac.id/33679/

Kusmaria, K., Asmarantaka, R. W., \& Harianto, H. (2017). Analisis Penentuan Rafaksi Dan Pengaruhnya Terhadap Pilihan Saluran Pemasaran Petani Ubi Kayu Di Kabupaten Lampung Tengah. Forum Agribisnis, 6(2), 129-144. https://doi.org/10.29244/fagb.6.2.129144

Lanamana, W., \& Philipus, N. S. (2020). Faktor-Faktor yang Mempengaruhi Pendapatan dan Prospek Usahatani Ubi Kayu Varietas Lokal Nuabosi di Desa Randotonda Kecamatan Ende Kabupaten Ende. Jurnal Sosio Agribisnis, 5(2), 94-103. https://doi.org/http://dx.doi.org/10.3377 2/jsa.v5i2.14047

Leksono, T. B., Supriyadi, S., \& Zulkarnain, Z. (2018). Analisis Perbandingan 
Pendapatan Usahatani Padi Organik Dan Anorganik Kecamatan Seputih Banyak Kabupaten Lampung Tengah. Jurnal Wacana Pertanian, 14(2), 6979.

https://doi.org/http://dx.doi.org/10.3769 4/jwp.v14i2.45

Lestari, D. A. H., Prasmatiwi, F. E., \& Ismono, R. H. (2018). Analisis Perbandingan Biaya Transaksi, Pendapatan, dan Kesejahteraan Petani Kelapa Sawit Plasma dengan Swadaya di Kabupaten Tulang Bawang. AGRARIS: Journal of Agribusiness and Rural Develpoment Research, 4(2), 111-119. https://doi.org/DOI: http://dx.doi.org/10.18196/agr.4266

Machfudz, M., \& Khoiriyah, N. (2013). Analisis Ketahanan Pangan Melalui Pemodelan Usaha Tani Singkong. Iqtishoduna, $9(1), \quad 1-15$. https://doi.org/https://doi.org/10.18860/i q.v0i0.2285

Malian, A. H., Rachman, B., \& Djulin, A. (2004). Permintaan Ekspor dan Daya Saing Panili di Provinsi Sulawesi Utara. Junal Agro Ekonomi, 22(1), 26-45. http://repository.pertanian.go.id/handle/ $123456789 / 240$

Meliyana, R., Zakaria, W. A., \& Nurmayasari, I. (2013). Daya Saing Lada Hitam di Kecamatan Abung Tinggi Kabupaten Lampung Utara. Jurnal Ilmu Ilmu Agribisnis, 1(4), 271277.

https://doi.org/http://dx.doi.org/10.2396 0/jiia.v1i4.271-277

Muslika, R., \& Tamami, N. D. B. (2019). Daya Saing Komoditas Ekspor (Karet) Indonesia Ke China. Agriekonomika, $8(2)$, 194-205. https://doi.org/10.21107/agriekonomika .v8i2.5426

North \& Thomas. 1973. Rise of the Western World a New Economic History. Cambridge University Press : Australia

Patria, A. D., Adrianto, L., Kusumastanto, T., Kamal, M. M., \& Dahuri, R. (2014). Biaya Transaksi Usaha Perikanan Skala
Kecil Di Kabupaten Cilacap. Jurnal Sosial Ekonomi Kelautan Dan Perikanan, 9(2), 247-254. https://doi.org/http://dx.doi.org/10.1557 8/jsekp.v9i2.1225

Pramesti, F. S., Rahayu, E. S., \& Agustono, A. (2017). Analisis Daya Saing Ubi Kayu Indonesia Di Pasar Internasional. SEPA: Jurnal Sosial Ekonomi Pertanian Dan Agribisnis, 14(1), 1-7. https://doi.org/10.20961/sepa.v14i1.210 34

Ramadan N, R. (2018). Analisis Daya Saing Komoditas Ubi Kayu di Kecamatan Lengkong Kabupaten Sukabumi. Jurnal Penelitian Dan Pengembangan Sains Dan Teknologi, 12(2), 55-62. http://eprints.ummi.ac.id/id/eprint/795

Rosanti, N., Zakaria, W. A., Hasyim, A. I., \& Kasymir, E. (2018). Analisis Daya Saing Ubi Kayu di Provinsi Lampung. Jurnal Sosial Dan Ekonomi Pertanian, 12(1), 62-74. https://jurnalfp.uisu.ac.id/index.php/sep/ article/view/20

Rozi, F., \& Pudjiastuti, A. Q. (2019). Produk Samping Tanaman Ubikayu Sebagai Potensi Bioekonomi Untuk Pertanian Masa Depan. SOCA: Jurnal Sosial Ekonomi Pertanian, 13(3), 433446.

https://doi.org/10.24843/soca.2019.v13. i03.p12

Saidah, Z. (2018). Analisis Biaya Produksi dan Biaya Transaksi Pada Usahatani Cabai Merah (Capsicum Annum L). UNES Journal Agricultural Scienties, 2(1), 27-40. http://journal.univekasakti-

pdg.ac.id/index.php/agriculturalANALI SIS

Saptana, S., Friyatno, S., \& Bastuti P, T. (2004). Analisis Dayasaing Komoditi Tembakau Rakyat Di Klaten Jawa Tengah. SOCA: Socioeconomics of Agriculture and Agribusiness, 4(2), 126.

https://ojs.unud.ac.id/index.php/soca/art icle/view/4048 
Saragih, J. R., Siburian, A., Harmain, U., \&Purba, T. (2021). Komoditas Unggulan dan Potensial Sektor Pertanian Kabupaten Simalungun Provinsi Sumatera Utara. Agro Bali: Agricultural Journal, 4(1), 51-62. https://doi.org/10.37637/ab.v4i1.633

Sari, L. R., \& Fahmi, A. (2018). Dampak Subsidi Pupuk Terhadap Peningkatan Pendapatan dan Kesejahteraan Petani Kecamatan Megaluh Jombang Dalam Perspektif Fenomenologis (Studi Kasus Dusun Sudimoro dan Dusun Paritan). MARGIN ECO: Jurnal Bisnis Dan Perkembangan Bisnis, 2(2), 86-101. https://doi.org/https://doi.org/10.32764/ margin.v2i2.328

Sari, N. M., \& Retnaningsih, E. (2020). Strategi Pengembangan Science Techno Park Melalui Ekosistem Inovasi Dalam Rangka Peningkatan Daya Saing Daerah Provinsi Sumatera Selatan. Penelitian Terapan Dan Kebijakan, 3(1), 1-20. https://doi.org/https://doi.org/https://doi. org/10.46774/pptk.v12i1.114

Sinaga, Y. J., Lestari, D. A. H., \& Situmorang, S. (2019). Keragaan Agroindustri Mi Basah Di Kota Bandar Lampung Dan Perilaku Konsumen Dalam Perspektif Diversifikasi Pangan. Jurnal Ilmu Ilmu Agribisnis, 7(3), 338345.

https://doi.org/http://dx.doi.org/10.2396 0/jiia.v7i3.338-345

Suciati, L. P., Juanda, B., Fauzi, A., \& Rustiadi, E. (2014). Peran Kelembagaan Perdesaan untuk Keberlanjutan Penerapan SRI di Kabupaten Karawang. Jurnal Ekonomi Dan Pembangunan Indonesia, 14(2), 109127.

https://doi.org/https://doi.org/10.21002/j epi.v14i2.567

Sugino, T., \& Mayrowani, H. (2009). The Determinants of Cassava Productivity and Price Under The Farmers' Collaboration With The Emerging Cassava Processors: A Case Study in
East Lampung, Indonesia. Journal of Development and Agricultural Economics, 1(5), 114-120. http://www.academicjournals.org/JDAE Sukmaya, S. G., Rachmina, D., \& Saptana, S. (2017). Analisis Daya Saing Dan Dampak Kebijakan Pemerintah Terhadap Komoditas Kedelai Vs Pengusahaan Kedelai Di Kabupaten Lamongan, Jawa Timur. Forum Agribisnis, 6(1), 21-52. https://doi.org/10.29244/fagb.6.1.21-52

Sultan, H., \& Rachmina, D. (2017). Pengaruh Biaya Transaksi Terhadap Keuntungan Usahatani Kedelai Di Kabupaten Lamongan, Jawa Timur. Forum Agribisnis, 6(2), 161-178. https://doi.org/https://doi.org/10.29244/ fagb.6.2.161-178

Widyatami, L. E., \& Wiguna, A. A. (2019). Daya Saing dan Dampak Kebijakan Pemerintah terhadap Usahatani Padi Sri di Kecamatan Rogojampi Kabupaten Banyuwangi. AGRARIS: Journal of Agribusiness and Rural Development Research, 5(2), 99-111. https://doi.org/http://dx.doi.org/10.1819 6/agr.5279

Yuliati, L., Nasir, M. A., \& Subagiarta, I. W. (2019). Analisis Daya Saing Komoditas Singkong Kabupaten Jember Di Jawa Timur. Prosiding Seminar Nasional Penelitian \& Pengabdian Kepada Masyarakat, 452457.

Zakaria, A. K., Sejati, W. K., \& Kustiari, R. (2010). Analisis Daya Saing Komoditas Kedelai Menurut Agro Ekosistem: Kasus di Tiga Provinsi di Indonesia. Jurnal Agro Ekonomi, 28(1), 21-37. https://doi.org/10.21082/jae.v28n1.2010 $.21-37$

Zakaria, W. A., Endaryanto, T., Ibnu, M., \& Marlina, L. (2019). Kesediaan Petani Melakukan Kemitraan Dimasa Datang: Analisis Heckprobit Pada Petani Ubi Kayu Di Provinsi Lampung. Journal of Tropical Upland Resources (J. Trop. Upland Res.), 1(1), 19-34. 
https://doi.org/https://doi.org/10.23960/j tur.vol1no1.2019.7

Zakaria, W. A., Endaryanto, T., Mas Indah, L. S., Mellya Sari, I. R., \& Mutolib, A. (2020). Pendapatan Dan Kesejahteraan Rumah Tangga Petani Ubikayu Di Provinsi Lampung. Jurnal Agribisnis Indonesia, $\quad 8(1), \quad 83-93$. https://doi.org/https://doi.org/10.29244/j ai.2020.8.1.83-93

Zulkarnain, Z., Haryono, D., \& Kasymir, E. (2010). Keunggulan Komparatif dan Kompetitif dalam Produksi Padi di Kabupaten Lampung Tengah Propinsi Lampung. Jurnal Penelitian Pertanian Terapan, 10(3), 185-199. https://doi.org/https://doi.org/10.25181/j ppt.v10i3.262

Zulkarnain, Z., \& Mangiring, W. (2017). Analisis Biaya Transaksi pada Kelembagaan Pertanian Gapoktan Penerima Program Pengembangan Usaha Agribisnis Pedesaan (PUAP) di Desa Raman Aji Kecamatan Raman Utara Kabupaten Lampung Timur. Jurnal Penelitian Pertanian Terapan, 17(3), 186-196. https://doi.org/http://dx.doi.org/10.2518 1/jppt.v17i3.325

Zulkarnain, Z., Zakaria, W. A., Haryono, D., \& Murniati, K. (2020). Determination of Cost of Sold Goods in Tapioca Factory of Cluster I and Cluster II in Lampung Province. International Journal of Advanced Science and Technology, 29(4), 5227-5234. http://sersc.org/journals/index.php/IJAS T/issue/vi... 